\title{
The Effects of Probation Stipulations on Perceptions of Employability Among People on Probation in Rhode Island
}

\section{Jesse Capece}

\begin{abstract}
Roughly one-third of the people under the purview of the Rhode Island Department of Corrections are on active probation. People on probation are typically mandated to a variety of stipulations, such as meetings with their probation officer, court appointments, drug and/or mental health counseling, and crime-specific stipulations, such as anger management groups. Evidence suggesting that mandating these stipulations reduces a person's likelihood to be rearrested is minimal. In contrast, there is a wealth of evidence suggesting that stable employment decreases recidivism. A person's perceptions of their employability have been demonstrated as a key component to both pursuing and maintaining employment opportunities. Drawing on Labeling Theory, this study surveyed 170 persons on active probation to explore the correlation between probation stipulations and employability perceptions. Results suggest there is a negative association between stipulations and perceptions of employability. Social work practitioners working with people on probation or people who are incarcerated should work to increase their clients' perceptions of employability.
\end{abstract}

Keywords: Prisoner reentry, probation, ex-offenders, employability

The vast majority (97\%) of our nation's two million incarcerated people have sentences that end in a release from prison (Bureau of Justice Statistics, 2020). The majority of people who have been in prison will be mandated to some form of community supervision, such as probation, once released. These individuals will join an estimated five million Americans already on probation or parole (Bureau of Justice Statistics, 2020).

Community supervision is used, to some capacity, throughout the nation. Some states rely on it more heavily than others. Rhode Island has the second highest rate in the nation of people under community supervision, with nearly 2,800 out of every 100,000 people being on either probation or parole (Bureau of Justice Statistics, 2020). The Rhode Island Department of Corrections (RIDOC) Population Report indicates that there were 26,039 people in the custody of the RIDOC at the end of fiscal year 2017 (RIDOC, 2017). Only $2,958(11.4 \%)$ of these 26,039 were incarcerated. The remaining 23,081 live in the community and are under the supervision of the RIDOC, with the vast majority (96.9\%) being on probation.

Rhode Islanders on probation can be classified into three levels of supervision: active, low, or unsupervised. Active supervision requires the most contact with the probation officer, while unsupervised requires the least. Roughly 8,400 Rhode Islanders on probation are on active supervision, which carries the most requirements, including regular visits to the probation office, mandated drug treatment, or mandated mental health counseling. People on probation who demonstrate to the RIDOC that they no longer need active supervision can transition to low or unsupervised status. As a result of some infraction or

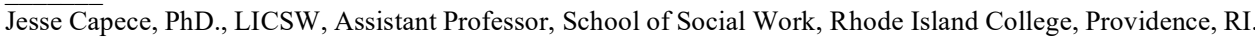

Copyright (C) 2020 Authors, Vol. 20 No. 3 (Fall 2020), 578-595, DOI: 10.18060/23895 
added criminal sentence, people on probation can be transitioned back to active supervision.

Rhode Island is pushing to rapidly exit people from the prison's physical facilities, opting to put them under community supervision (Beale, 2011; RIDOC, 2015). People who were once in prison in Rhode Island must adhere to a variety of probation stipulations. Prevailing evidence suggests that employment reduces recidivism (Delgado, 2012; Laub \& Sampson, 2003; Petersilia, 2009). Research on the impact of positive feelings of employability are limited and dated, though results suggest that they are positively correlated with employment outcomes (Artess et al., 2016; Daniels et al., 1998; Green, 2011; Herr et al., 2004).

Patterson (2013) suggests that reentry issues are not simply a matter of importance to people who have been in prison and their families, but to the entire community. Indeed, successfully transitioning people back to the community after time in prison is essential to obtaining and sustaining the health and security of all members of a community (Patterson, 2013). Despite the importance of employment to reentry success (Delgado, 2012; Laub \& Sampson, 2003; Petersilia, 2009), there is a lack of research on the impact of mandated probation on perceptions of employability. The goal of this study was to answer the question: How do probation stipulations impact self-perceptions of employability amongst people who have been in prison? This study hypothesized that people on probation with fewer stipulations will have more favorable perceptions of employability than people on probation with more stipulations. A secondary aim of this study was to contribute to the store of knowledge from which social workers working with people involved in the prison and policing systems might draw. People who have been in prison are disproportionately composed of people of color and people living in poverty (Sentencing Project, 2018). Therefore, many probationers are not only historically oppressed, but are also current targets of systematic forms of oppression. Social workers are professionally obligated to work with, advocate for, and conduct research on behalf of such populations and disseminate findings in order to inform policy (National Association of Social Workers, 2017, Preamble, ethical standard 6.04b).

\section{Theoretical Framework}

Labeling theory is used to explain how an individual's identity and behavior are influenced by the terms society uses to describe and understand them. When a community assumes that a group behaves in a deviant manner, such assumptions contribute to group members internalizing the label and developing a negative self-concept (Lemert, 1951, 1967). The foundation of labeling theory was laid by George Herbert Mead (1934), who suggested that behaviors are driven by individual beliefs about self, and those beliefs about self are a reflection of other's beliefs about them. Lemert $(1951,1967)$ posits that deviant acts are social acts and, when repeatedly labeled as deviant in the eyes of society, people internalize the role of a deviant and it becomes a component of their identity. Lemert further points out that everyone commits deviant acts, but not everyone is labeled as deviant. However, once a person is labeled as deviant and the characteristics of a deviant become part of that person's identity, they then may use the label of deviant as a defense mechanism and as a justification for action. Becker (1963) describes this as an alteration of self- 
concept, where the labels that larger society gives a person disrupt their self-image. It is possible that mandating people to attend events such as probation meetings, court appearances, and mandatory drug treatment among other stipulations, are all acting as reminders to people on probation of the deviant label they carry. Kaopua et al. (2012) concluded that it is extremely difficult for a person to shake the stigma associated with the label of ex-convict. This researcher posits that the continuous reminder of one's deviant label (by ongoing stipulations) negatively impacts their perceptions of employability.

\section{Employment and Recidivism}

Significant hardship is associated with unemployment, both for individuals (Schmitz, 2011) and communities (Kuhn et al., 2009). Unemployment among people who have been in prison is accompanied by the additional risk of an increased chance of recidivating. The leading reason that people do not return to prison is that they age (Laub \& Sampson, 2001). When controlling for age, however, evidence suggests that employment is the largest contributor to a reduction in recidivism (Laub \& Sampson, 2003). Efforts to transition people from prison back to the community must be focused on employment issues if we wish to promote health and stability for individuals and communities (Solomon et al., 2004). Petersilia (2009) and Delgado (2012), leading scholars in reentry efforts, echo these sentiments. Both point to employment as the most important factor for successfully transitioning people from prison to communities. Employment has been shown to bring significant benefits to individuals, in particular individuals belonging to historically difficult-to-employ populations, such as people who are homeless and people with cooccurring disorders (Sun, 2012).

\section{Release Stipulations and Employment Outcomes}

The majority of the Rhode Islanders on probation have at least one mandated condition related to their release. Mandated stipulations may include court appearances to pay various debts, such as restitution, child support, and/or arrearages, meetings with probation officers, treatment for substance use or mental health struggles, and/or participation in specialized programming like domestic violence or anger management classes. People on probation who do not adhere to these conditions could be sent back to prison. Unfortunately, there is no data that demonstrates the frequency or number of people returned to prison because of missing a mandated appointment. Worth noting, however, is that of the 12,933 commitments to the RIDOC in fiscal year $2019,26 \%(3,362)$ were for probation violations (RIDOC, 2019). It is reasonable to assume that some of these violations are because of a failure to adhere to the mandated stipulations.

Previous research has suggested that a positive relationship exists between the intensity of probation and employment (Petersilia \& Turner, 1991). Researchers studied people on probation who were receiving intense and non-intense supervision. Results suggest that people receiving more intense supervision were only slightly more likely to have a job than those with less intense stipulations. A limitation of the Petersilia and Turner (1991) study includes employment being defined as anything the study participants were employed to do during an entire year, which does not take into account critical details of a job, such as wages, hours worked per week, or length of time on the job. Finally, this research, having 
been conducted nearly thirty years ago, does not account for various significant shifts in the employment market and probation population. More recent studies, however, suggest that there is a negative correlation between intensity of probation and employment outcomes. Capece (2020) posits that the more probation appointments a person is mandated to attend, the worse their employment outcomes will be.

\section{Employability}

Race, gender, education level, and a variety of other factors can influence the likelihood of a person getting a job. Those variables, along with some others that play a significant role in the lives of people on probation, are potential moderating variables in this study. These variables, which influence a person's employability, are different than individual's perceptions of their employability. There is some evidence of the role perceptions of employability play for people who have not been in prison (Qenani et al., 2014). Variables that influence a person's employability include: race, gender, type of criminal conviction, support from family and friends, access to transportation, mental health, substance abuse, and education.

Race

Just as race-based implicit bias impacts a person's experience in the criminal justice system, it also impacts their experiences in the labor market. Various studies have highlighted the racial disparities that exist when it comes to employment outcomes (Bertrand \& Mullainathan, 2004; Pager \& Shepherd, 2008; Tomaskovic-Devey et al., 2005). An analysis of population data by Pager and Shepherd (2008) reveals that people of African-descent are twice as likely to be unemployed than people of European-descent. One reason for this disparity in unemployment is the discrimination that people of Africandescent face when applying for jobs. Bertrand and Mullainathan (2004) posit that simply having a name that suggests to an employer that you are of African descent is enough to have your application for employment rejected. They arrived at this conclusion after sending identical resumes to employers with the only difference being the name of the applicant. Results suggest that applicants named Emily and Greg were more likely to be hired than applicants named Jamal and Lakisha. Similar discrimination was highlighted by Tomaskovic-Devey et al. (2005), who concluded that men of African-descent spend more time trying to obtain employment, yet ultimately gain less work experience and less work stability. Additionally, once employed, wages of both African-descent and Latinx-descent people are less than people of European-descent (Pager \& Shepherd, 2008).

\section{Gender}

A 2015 report from the Bureau of Labor Statistics indicates that women earn an average of $82 \%$ of the median wages that men earn per week. Earlier reports from the Bureau of Labor Statistics (2020) suggest similar gender differences, with women regaining employment at a slower pace than men after the 2008 recession despite having attained higher levels of education. Given these realities, it is essential to collect information about participants' gender in this study of employment outcomes. 


\section{Type of criminal conviction}

The nature of a person's criminal conviction has shown to have an influence on the employment of people on probation. Research suggests that people convicted of a drug offense or a traffic offense are more likely to be hired than those convicted of a violent crime (Atkin \& Armstrong, 2011; Giguere \& Dundes, 2002). Research by Holzer et al. (2003) reveals the intensity of the aversion that employers have to hiring people on probation who have a violent charge. Results of their study show that $90 \%$ of employers disclosed that they would not hire someone convicted of a violent offense. Additional aversion to hiring people convicted of sexual offenses is also documented (Albright \& Denq, 1996). No specific research suggests that there is a causal relationship between having a specific crime(s) on one's criminal record and self-perceptions of employability. Nevertheless, it is likely that people with criminal records that carry additional social stigma, such as child molestation or murder, may have lower perceptions of employability than people with less stigmatizing criminal histories.

\section{Support from friends, family and romantic partners}

The role of family members and their support are critical to psychological well-being (Huffman et al., 2015). The support of family and friends also helps to enhance the selfesteem of those who are unemployed (Maddy et al., 2015). Social networks are critical to obtaining a job, as a person's likelihood of doing so is greatly improved if they have a personal friend who works at that job (Sterling, 2014).

\section{Access to transportation}

Access to transportation, particularly public transportation, impacts a person's ability to find and maintain employment (Fletcher et al., 2002, 2010). Barriers to reliable transportation exist across a variety of settings, as both urban and rural residents struggle to get to work (Angel \& Blei, 2016; Fletcher et al., 2010). Additional studies highlight the importance of having access to reliable transportation specifically among people involved in community supervision (Bohmert \& DeMaris, 2018).

\section{Mental health and substance abuse}

A disproportionate number of people in prison or on probation have a mental illness compared to the overall US population (James \& Glaze, 2006; Skeem \& Louden, 2006; Steadman et al., 2009). According to a comprehensive assessment, $64 \%$ of people in local jails, $56 \%$ of people in state prisons, and $45 \%$ of people in federal prisons have symptoms of serious mental illness (James \& Glaze, 2006). Additionally, nearly 50\% of people in US prisons have a substance use disorder (Chandler et al., 2009; Mumola \& Karberg, 2006; Peters et al., 1998). Studies have demonstrated that the presence of mental illness, substance abuse, or both, is a barrier to obtaining and maintaining employment (Atkinson et al., 2001; Harris et al., 2014; Pilkinton, 2010; Poremski et al., 2014; Stromwell, 2001). 


\section{Education}

Level of education has long been a predictor of employment outcomes in the United States. Data collected by the Bureau of Labor Statistics (2018) highlight the differences in pay for various educational levels. Median wages earned per week increased, regardless of gender or racial identity, at every education level ranging from less than a high school diploma to an advanced degree. Individuals with advanced degrees, the highest level of education recorded, earned $300 \%$ more per week than those with less than a high school education, the lowest level of education recorded. This same report reinforces previously mentioned mediating variables of race and gender. Within each category of education, women consistently earn less per week than men and African-descent people consistently earn less than Latinx-descent people, who earn consistently less than European-descent people.

\section{Additional demographics}

In their longitudinal study of people on probation, Visher et al. (2008) posed a variety of questions related to potential mediating demographics. These items helped them to gather information on physical health, length of time since release from prison, and city/town of residence. Demographic items about these issues were included in this research as control variables.

\section{Perceptions of Employability}

Largely ignored by researchers is the possible connection between the perceptions of employability of people who have been in prison and their stipulations of release. This is unfortunate, as many researchers suggest that feeling employable plays a major role for people who have not been in prison when it comes to securing employment. Green (2011) used nationally representative panel data from Australia's general population to show that an increased feeling of employability decreases roughly $75 \%$ of the negative effects of unemployment. Green suggests that feeling employable combats the "misery multiplier" (p. 265) that magnifies struggles faced during periods of unemployment. Herr et al. (2004) suggest that perceptions of one's employability are heavily influenced by having a job in the first place, while Artess et al. (2016) suggest that feeling employable is a catalyst for getting a job. Though the direction of the causal relationship is ambiguous, it seems that quality of employment and perceptions of employability are linked.

In testing the validity and reliability of a perceived employability scale, Daniels et al. (1998) showed that an individual's perception of their employment prospects impacts their ability to find and maintain a job. Their perceptions are positively correlated with actual employment outcomes. Similar suggestions are supported by Qenani et al. (2014), who suggest that self-perceptions of one's employability impact expectations of employment. Though the sample for this study included undergraduate psychology students, their study does support the claims that perceived employability impacts employment expectations and that formal institutions, such as schools, can foster and boost feelings of employability. Most of these studies have investigated the perception of employability on general or student populations; this has not yet been investigated for the formally incarcerated 
population. Additionally, these studies seem to measure the personal construction of perceptions of employability without also measuring how the environment contributes to those personal constructions. It is possible that environmental factors and experiences in the community have a significant influence on a person's perceptions of employability. Such factors were included as moderating and mediating variables in the present study.

\section{Methods}

The goal of this study was to explore the association between release stipulations and perceptions of employability among persons on probation. Given the myriad of potential mediating factors that exist in the relationship between probation stipulations and perceptions of employability, a larger sample is needed to establish an association. A crosssectional design was used to collect survey data during the spring and summer of 2017. Participants were recruited in probation office waiting rooms and probation forums. Probation forums are gatherings of many people on probation at one time. The forums are held at various locations throughout Rhode Island. The RIDOC granted access to the probation office waiting rooms and forums for people on probation. Potential participants were asked if they were willing to complete a survey about being on probation and their experiences with getting and keeping a job. The survey was conducted as part of a larger study measuring various employment outcomes. Participants were asked to not put their name or any identifying information on the surveys. Participants were given envelopes that contained the survey, an information sheet describing the study, a pen, and a \$5 Dunkin Donuts gift card which was compensation for participants' time. Respondents were asked to put the completed surveys back into the envelopes and drop those envelopes into an opaque box near the exit of the room. Participants were told that they did not need to answer any questions they did not want to and that they could keep the gift card even if they did not complete the survey. Participants were in no way mandated or required to engage in the study. The study was approved by the university's IRB and the RIDOC's Medical Review Advisory Board.

\section{Sample}

People on active supervision in Rhode Island represent the total population for this study (roughly 8,400), which was part of a larger dissertation project. This population includes many of the most recently released persons with the highest likelihood of returning to prison (RIDOC, 2015). This population is an estimate, as the precise number continuously changes. A power analysis was conducted to calculate an adequate sample size for this study. Power analysis is the ability to find a statistically significant difference when the null hypothesis is in fact false, or the ability to find a difference when a real difference exists (Tabachnick \& Fidell, 2007). To ensure an adequate sample size based on the most complex questions on the survey, a sample of at least 170 participants was needed. This number was calculated using Tabachnick and Fidell's (2007) formula of $\mathrm{N} \geq 50+8 \mathrm{~m}$ : where $m$ is the maximum number of independent variables, which, for purposes of this study, was 15 . Therefore, $170 \geq 50+(8 * 15)$. 


\section{Instruments}

Data were collected via a survey which employed multiple choice, fill-in-the-blank, and Likert-scale questions. Participants identified how many times per month they must attend different stipulations. Perceptions of employability were measured by the 13-item Self-perceived Employability Scale. The 13 items came from five previous studies that examined perceived employability (Daniels et al., 1998; De Cuyper et al., 2011; Graffam et al., 2008; Janssens et al., 2003; Rothwell \& Arnold, 2007). Participants answered these items by using a four-point Likert-scale ranging from strongly agree to strongly disagree. The validity and reliability of the scale had not been assessed previously. The Cronbach's alpha of the scale when used in the study was .858, suggesting excellent internal consistency.

\section{Extraneous variables}

Extraneous variables were measured in a variety of ways. Portions of the Addiction Severity Index (ASI) were used to measure current drug use and mental health struggles, both potential control variables (McLellan et al., 1992). Moderating variables such as racial identity, type of criminal conviction, access to transportation and many others, were measured in the demographic section.

\section{Results}

\section{Demographics and significant control variables}

Table 1 summarizes the gender, race, and age of survey participants. As a result of missing data, some totals differ.

Table 1. Demographic and Control Variables With a Significant Influence

\begin{tabular}{l|r}
\hline Variables & n (\%) \\
\hline Gender $(n=168)$ & $144(85.7 \%)$ \\
Male & $21(12.5 \%)$ \\
Female & $3(1.8 \%)$ \\
Transgender & $62(36.9 \%)$ \\
\hline Race $(n=168)$ & $60(35.7 \%)$ \\
White non-Hispanic & $38(22.6 \%)$ \\
Black/African American & $8(4.8 \%)$ \\
Latino/Hispanic American & \\
Other & $54(36.2 \%)$ \\
\hline Age $($ years, $n=149)$ & $49(32.9 \%)$ \\
$<=32$ & $46(30.9 \%)$ \\
$33-45$ & \\
$46+$ &
\end{tabular}

It is worth noting that the percentages of male and female study participants is nearly identical to the percentages of males and females currently committed to the RIDOC (the 
annual population report of the RIDOC does not indicate the number of transgender people in their prisons): $84.4 \%$ and $15.6 \%$ respectively (RIDOC, 2017). The most common racial identity of participants was White, non-Hispanic (36.9\%). The racial profile of the study sample, however, is substantially different than people imprisoned at the RIDOC. Racial identities of people currently imprisoned in Rhode Island is $51.7 \%$ White, $23.4 \%$ Black, and 20.8\% Hispanic (RIDOC, 2017). Compared to the general US population, people of color are over-represented in the study sample. This reinforces existing data that suggests massive racial disparities in the prison and policing systems (Sentencing Project, 2018).

\section{Independent variables}

Table 2 summarizes the frequency that participants are mandated to attend specific probation stipulations. This table has been provided to give a sense of the frequency of appointments as well as the variety of stipulations to which they are mandated. Appointments with probation officers was the most common stipulation to which participants must attend at least once per month (95.2\% of participants must go to probation at least once per month). The average number of probation appointments per month was $1.4(\mathrm{SD}=.86)$. Court appearances were the second most common stipulation to which participants must attend at least once per month $(56.9 \%$ of participants must go to court at least once per month). The average number of court appearances per month was $1.6(\mathrm{SD}=$ $.94)$.

Table 2. Stipulations Per Month $(n=168)$

\begin{tabular}{l|r|c|r}
\hline Stipulation & $\begin{array}{c}\text { Attended at least } \\
\text { once/month } \\
\text { n (\%) }\end{array}$ & Median & $\begin{array}{c}\text { Mean } \\
\text { (SD) }\end{array}$ \\
\hline Probation & $159(95.2 \%)$ & 1 & $1.4(0.86)$ \\
Court & $94(56.9 \%)$ & 1 & $1.6(0.94)$ \\
Therapy/counseling & $73(43.2 \%)$ & 2 & $2(1.22)$ \\
Outpatient drug/alcohol treatment & $48(30 \%)$ & 3 & $3(1.66)$ \\
Alcoholics/Narcotics Anonymous & $42(24.9 \%)$ & 3 & $3(1.49)$ \\
Sex offender treatment & $25(15 \%)$ & 3 & $2.9(1.50)$ \\
Domestic violence classes & $16(9.5 \%)$ & 3 & $3(1.32)$ \\
Anger management classes & $11(6.8 \%)$ & 2 & $2(1.27)$ \\
Driver's training & $6(3.5 \%)$ & 2 & $2(1.37)$ \\
Other & $11(7.9 \%)$ & 1 & $1.7(1.01)$ \\
\hline
\end{tabular}

\section{Dependent variables}

Table 3 summarizes the participants' perceptions of employability. Each of the 13 items in the Employability Scale (questions 1-12 and 15 in Part 3 of the survey) were scored as follows: Strongly disagree $=1 ;$ Disagree $=2 ;$ Agree $=3$; and Strongly agree $=4$. The sum of the scores for these 13 items represents a participant's overall perception of employability. Roughly one-third perceived their employability in each category-weak, moderate, or strong, suggesting high variability. 
Table 3. Perceptions of Employability $(n=166)$

\begin{tabular}{l|c}
\hline Perceived employability* & $\mathbf{n ~ ( \% )}$ \\
\hline Weak (33 or less) & $61(36.7 \%)$ \\
Moderate (34-40) & $50(30.1 \%)$ \\
Strong $(41+)$ & $55(33.1 \%)$ \\
\hline * $M d n=36, M=35.61, S D=8.55$, range $=10-52$ \\
\hline
\end{tabular}

Table 4 presents the results of a Pearson's Correlation between the dependent variable (perceptions of employability), the independent variable (mandated stipulations), and various control variables (variables 3 through 11). As expected, there was a negative correlation between the total number of stipulations a person on probation must attend each month and their perceptions of employability. Although this association is statistically significant, the total variance in perceptions of employability that is explained by total stipulation was minimal.

\section{Association of Number of Stipulations and Perceptions of Employability}

A standard multiple regression analysis, presented in Table 5, was used to test if total stipulations per month predict participants' perceptions of employability when controlling for age, use of public transportation as a primary form of transportation, a middle school education (dummy coded), and being homeless (dummy coded). These variables were included in the model as they were significantly correlated with perceptions of employability. The hypothesis, drawing from Labeling Theory, was that people on probation with fewer stipulations will perceive themselves as more employable than those with more stipulations. Results of the regression analysis seem to suggest that there is a negative association between total mandated stipulations per month and perceptions of employability when controlling for other factors significantly correlated with perceptions of employability. While there was a statistically significant effect, the results are not substantive, as the total variance in perceptions of employability that was explained was minimal $(11.9 \%)$.

\section{Discussion}

Results of this study suggest a negative correlation between number of stipulations and perceptions of employability among probationers. Though significant, the associations are not substantive, given the minimal to moderate effect sizes. Nevertheless, results have implications for both case and group work in settings with people who have been in prison as well as with policy advocates and researchers engaged in reform of prison and policing systems. As Daniels et al. (1998) suggest, an individual's perception of their employment prospects is positively correlated with their ability to not just find a job but maintain one as well. The correlation in the Daniels et al. (1998) study between having a job and positive perceptions of employability supports such a conclusion. The strong Cronbach's alpha of the scale used in this employability scale (.858) further supports the reliability of the items used in the scale. Results suggest that the questions originally used by Daniels et al. (1998), De Cuyper et al. (2011), Graffam et al. (2008), Janssens et al. (2003), and Rothwell and Arnold (2007) may work well in concert with one another. 
Table 4. Perceived Employability, Independent and Significant Control Variables

\begin{tabular}{|c|c|c|c|c|c|c|c|c|c|c|c|c|}
\hline Variable & M (SD) & 1 & 2 & 3 & 4 & 5 & 6 & 7 & 8 & 9 & 10 & 11 \\
\hline 1. Perceptions $(n=166)$ & $35.6(8.55)$ & 1 & $-.155^{*}$ & $.371^{* *}$ & .121 & .001 & $-.204^{*}$ & $-.328^{* *}$ & $-.231^{* *}$ & $-.172^{*}$ & $-.176^{*}$ & $-.182^{*}$ \\
\hline 2. Total stipulations $(n=170)$ & $7.7(5.24)$ & & 1 & -.040 & $-.186^{*}$ & $.284^{* *}$ & $.296^{* *}$ & -.078 & .090 & $.240^{* *}$ & .145 & -.051 \\
\hline 3. Friend/partner support $(n=162)$ & $5(1.92)$ & & & 1 & .096 & .015 & -.062 & $-.170^{*}$ & -.002 & $-.197^{*}$ & -.037 & .013 \\
\hline 4. Owns a car $(n=170)$ & -- & & & & 1 & $-.198^{*}$ & $-.281^{* *}$ & -.110 & $-.172^{*}$ & $-.661^{* *}$ & $-.327^{* *}$ & -.096 \\
\hline 5. Drug use (recent) $(n=167)$ & $5(7.45)$ & & & & & 1 & $.377^{* *}$ & -.096 & $.252^{* *}$ & $.177^{*}$ & .084 & .124 \\
\hline 6. $\mathrm{MH}$ disruption (recent) $(\mathrm{n}=160)$ & $6(5.5)$ & & & & & & 1 & .072 & .094 & $.264^{* *}$ & .137 & .109 \\
\hline 7. Age $(n=149)$ & $38.7(11.52)$ & & & & & & & 1 & .087 & .136 & .006 & $.241^{* *}$ \\
\hline 8. Drug conviction $(n=158)$ & -- & & & & & & & & 1 & $.160^{*}$ & $.223^{* *}$ & .090 \\
\hline 9. Public transportation $(n=170)$ & -- & & & & & & & & & 1 & $.352^{* *}$ & -.005 \\
\hline 10. Homeless $(n=170)$ & -- & & & & & & & & & & 1 & -.018 \\
\hline 11. Middle school educ. $(n=170)$ & -- & & & & & & & & & & & 1 \\
\hline
\end{tabular}

Table 5. Multiple Regression Analysis-

Predictors of Perceptions of Employability

\begin{tabular}{|l|r|r|r|}
\hline Predictor & \multicolumn{1}{|c|}{$\boldsymbol{B}$} & \multicolumn{1}{c|}{ Std. er. } & \multicolumn{1}{c|}{$\boldsymbol{\beta}$} \\
\hline Total stipulations per month & -.446 & .152 & $-.329^{*}$ \\
Age & -.145 & .079 & -.204 \\
Public transportation & .415 & 1.844 & .026 \\
Education is middle school (dummy var.) & 1.112 & 4.330 & .028 \\
Homeless (dummy var.) & -2.823 & 2.497 & -.130 \\
\hline \multicolumn{3}{|c}{} \\
\hline${ }^{*} p<.01$ & .175 \\
\\
$R^{2}=$ \\
Adjusted $R^{2}=.119$ \\
$R=$ & .419 \\
\end{tabular}


A limitation of this study is the subjective nature of self-perceptions of employability. Though the scale used in this study has a high Cronbach's alpha (.858), suggesting strong internal consistency, self-perceptions of employability likely encompass many other personal feelings and experiences. Future researchers in this area may wish to use a qualitative research design. With a qualitative approach, researchers could explore, possibly in focus groups, the effects of probation stipulations on feelings of employability. A qualitative study that is longitudinal may produce an even greater understanding of the relationship among the main variables in this study and expose significant control variables not measured by a quantitative approach. An additional limitation of this study is its inability to specify the origin of the labeling people on probation may experience. This research is unable to specify whether internalized negative self-concepts are coming from the label of being a person with a criminal record, a person with a substance use problem, or a person with a mental illness, all of which Lemert (1951) suggests carry negative labels. It is possible that participants with low perceptions of employability have such perceptions not because of the probation appointments to which they are mandated, but because of a substance use issue, a mental health issue, or another issue entirely. Future researchers may wish to include items that measure the type and origin of negative labels that participants may have.

\section{Implications for Social Work Practice}

A variety of potential policy recommendations exist related to mandated stipulations. For example, a potential change to the stipulation of probation may be to allow people on probation to connect with their probation officers via internet-based video communication applications such as Zoom, Facetime, Skype, or WhatsApp. Such measures have been used during the COVID-19 pandemic, though it is unclear if these measures will continue postpandemic. Permanently allowing such options could reduce the amount of time employed people on probation would need to take off of work and provide unemployed people on probation with more time to pursue and obtain a job. Another recommendation would be to expand the hours that probation offices are open, allowing those people on probation who are employed or have job interviews to attend probation meetings at times that do not conflict with their pursuit and maintenance of employment. Policy recommendations outside of the stipulation of probation might involve allowing people on probation opportunities to pay court fees online, as opposed to be required to physically appear in court. Additional changes to the stipulation of probation might involve allowances to people on probation with no means of paying court costs the opportunity to not have to go to court to begin with.

Given the importance of positive perceptions of employability, practitioners may want to organize support groups for people who have been in prison and have a heavy set of stipulations to which they must adhere. Worral et al. (2018) have highlighted the consistent pattern of effectiveness of support groups. In a support group setting, people on probation may find strength in the knowledge that others are experiencing the same barriers. Additionally, people on probation in group settings may be able to share tips and techniques for how to successfully navigate the pursuit and maintenance of employment whilst having many mandated appointments. 


\section{Conclusion}

Highlighting clients' strengths and abilities to positively contribute to the community is a task social workers engage in regardless of their area of practice. Results of this study suggest that enhancing a client's positive view of themselves may be of particular importance when working with people who have been incarcerated. If, as Labeling Theory suggests, people with criminal records have internalized the negative views the community has of them, then social work practitioners must work to counter such narratives. Countering such narratives might extend beyond the person on probation themselves and extend to counteracting the narrative that exists in the community as well. If, for example, social workers were to engage with the business community, they may be able to mitigate negative stereotypes and facilitate employment opportunities for people who have been incarcerated. Social workers working with people in the prison and policing systems should consider themselves on the frontline of combating the deep-rooted and historical negativity that is cast towards people with a criminal record.

\section{References}

Albright, S., \& Denq, F. (1996). Employer attitudes toward hiring ex-offenders. Prison Journal, 76, 118-137. https://doi.org/10.1177/0032855596076002002

Angel, A., \& Blei, A. (2016). The spatial structure of American cities: The great majority of workplaces are no longer in CBDs, employment sub-centers, or live-work communities. Cities, 51, 21-35. https://doi.org/10.1016/j.cities.2015.11.031

Artess, J., Hooley, T., \& Mellors-Bourne, R. (2016). Employability: A review of the literature 2012 to 2016. Higher Education Academy. https://s3.eu-west2.amazonaws.com/assets.creode.advancehe-documentmanager/documents/hea/private/resources/employability a review of the literature 1568037358.pdf

Atkin, C. A., \& Armstrong, G. S. (2011). Does the concentration of parolees in a community impact employer attitudes toward the hiring of ex-offenders? Criminal Justice Policy Review, 20, 1-23. https://doi.org/10.1177/0887403411428005

Atkinson, J., Lee, D., Dayton-Shotts, C., \& French, C. (2001). Self-perceived job skills and employment barriers among non-drug using and chronic drug using welfare-towork participants. Journal of Drug Issues, 31(3), 747-756. https://doi.org/10.1177/002204260103100311

Beale, S. (2011, March 18). Prison sentence reductions: RI most generous state in NE. GoLocal Prov. https://www.golocalprov.com/news/prison-sentence-reductions-rimost-generous-state-in-ne

Becker, H. (1963). Outsiders: Studies in the sociology of deviance. Free Press.

Bertrand M., \& Mullainathan, S. (2004). Are Emily and Greg more employable than Lakisha and Jamal? A field experiment on labor market discrimination. American Economic Review, 94, 991-1013. https://doi.org/10.1257/0002828042002561 
Bohmert, M. N., \& DeMaris, A. (2018). Cumulative disadvantage and the role of transportation in community supervision. Crime and Delinquency, 64(8), 1033-1056. https://doi.org/10.1177/0011128716686344

Bureau of Justice Statistics. (2020). Probation and parole in the United States, $2017-$ 2018. Department of Justice: https://www.bjs.gov/index.cfm?ty=pbdetail\&iid=6986

Bureau of Labor Statistics [BLS]. (2018). Weekly earnings by educational attainment in second quarter 2018. The Economics Daily. United States Department of Labor. https://www.bls.gov/opub/ted/2018/weekly-earnings-by-educational-attainment-insecond-quarter-2018.htm

BLS. (2020). Women in the labor force: A databook. BLS Reports. https://www.bls.gov/opub/reports/womens-databook/2018/home.htm

Capece, J. (2020). The effects of probation stipulations on employment quality among people on probation. Journal of Offender Rehabilitation, 59(7), 375-388. https://doi.org/10.1080/10509674.2020.1784348

Chandler, R. K., Fletcher, B. W., \& Volkow, N. D. (2009). Treating drug abuse and addiction in the criminal justice system: Improving public health and safety. Journal of American Medical Association, 301, 183-190. https://doi.org/10.1001/jama.2008.976

Daniels, J., D'Andrea, M., \& Gaughen, K. J. S. (1998). Testing the validity and reliability of the Perceived Employability Scale (PES) among a culturally diverse population. Journal of Employment Counseling, 35(3), 114-123. https://doi.org/10.1002/j.21611920.1998.tb00993.x

De Cuyper, N., Mauno, S., Kinnunen, U., \& Makikangas, A. (2011). The role of job resources in the relation between perceived employability and turnover intention: A prospective two-sample study. Journal of Vocational Behavior, 78(2), 253-263. https://doi.org/10.1016/j.jvb.2010.09.008

Delgado, M. (2012). Prisoner reentry at work: Adding business to the mix. Lynne Rienner Publishers.

Erwin, B. S. (1986). Turning up the heat on probationers in Georgia. Federal Probation, 50, 17-24.

Fletcher, C., Garasky, S., \& Jensen, H. H. (2002, February). Transiting from welfare to work: No bus, no car, no way. Paper presented at Hard-to-Employ and Welfare Reform Conference, Washington DC. https://www.researchgate.net/publication/5130891 Transiting from Welfare to Wo rk_No_Bus_No_Car_No_Way

Fletcher, C., Garasky, S., Jensen, H., \& Nielsen, R. (2010). Transportation access: A key employment barrier for rural low-income families. Journal of Poverty, 14(2), 123144. https://doi.org/10.1080/10875541003711581

Giguere, R., \& Dundes, L. (2002). Help wanted: A survey of employer concerns about 
hiring ex-convicts. Criminal Justice Policy Review, 13, 396-408.

https://doi.org/10.1177/088740302237806

Graffam, J., Shinkfield, A. J., \& Hardcastle, L. (2008). The perceived employability of ex-prisoners and offenders. International Journal of Offender Therapy \& Comparative Criminology, 52(6), 673-685. https://doi.org/10.1177/0306624x07307783

Green, F. (2011). Unpacking the misery multiplier: How employability modifies the impacts of unemployment and job insecurity on life satisfaction and mental health. Journal of Health Economics, 30(2), 265-276. https://doi.org/10.1016/j.jhealeco.2010.12.005

Harris, L. M., Matthews, L. R., Penrose-Wall, J., Alam, A., \& Jaworski, A. (2014). Perspectives on barriers to employment for job seekers with mental illness and additional substance-use problems. Health \& Social Care in the Community, 22(1), 67-77. https://doi.org/10.1111/hsc. 12062

Herr, E. L., Cramer, S. H., \& Niles, S. G. (2004). Career guidance and counseling: through the lifespan (6th ed.). Pearson Education.

Holzer, H. J., Raphael, S., \& Stoll, M. A. (2003). Employer demand for ex-offenders: Recent evidence from Los Angeles. Urban Institute Reentry Roundtable. http://citeseerx.ist.psu.edu/viewdoc/download?doi=10.1.1.594.5369\&rep=rep1\&type $=\mathrm{pdf}$

Huffman, A. H., Culbertson, S. S., Wayment, H. A., \& Irving, L. H. (2015). Resource replacement and psychological well-being during unemployment: The role of family support. Journal of Vocational Behavior, 89,74-82. https://doi.org/10.1016/j.jvb.2015.04.011

James, D. J., \& Glaze L. E. (2006). Mental health problems of prison and jail inmates. US Bureau of Justice Statistics. https://www.bjs.gov/content/pub/pdf/mhppji.pdf

Janssens, M., Sels, L., \& Van den Brande, I. (2003). Multiple types of psychological contracts: A six-cluster solution. Human Relations, 56(11), 1349-1378. https://doi.org/10.1177/00187267035611004

Kaopua, L. S. I., Petteruti A., Takushi R. N., Spencer J. H., Park S. H., Diaz, T. P., Kamakele, S. K., \& Kukahiko, K. C. (2012). The lived experience of Native Hawaiians exiting prison and reentering the community: How do you really decriminalize someone who's consistently being called a criminal? Journal of Forensic Social Work, 2(2-3), 141-161. https://doi.org/10.1080/1936928x.2012.746766

Kuhn, A., Lalive, R., \& Zweimüller, J. (2009). The public health costs of job loss. Journal of Health Economics, 28(6), 1099-1115. https://doi.org/10.1016/j.jhealeco.2009.09.004

Laub, J., \& Sampson, R. (2001). Understanding desistance from crime. Crime and Justice, 28, 1-69. https://doi.org/10.1086/652208 
Laub, J., \& Sampson, R. (2003). Shared beginnings, divergent lives: Delinquent boys to age 70. Harvard University Press. https://doi.org/10.1525/ctx.2004.3.4.64

Lemert, E. M. (1951). Social pathology: A systematic approach to the theory of sociopathic behavior. McGraw-Hill.

Lemert, E. M. (1967). Human deviance, social problems and social control. PrenticeHall.

Maddy, L., Cannon, J., \& Lichtenberger, E. (2015). The effects of social support on selfesteem, self-efficacy, and job search efficacy in the unemployed. Journal of Employment Counseling, 52(2), 87-95. https://doi.org/10.1002/joec.12007

McLellan, A., Kushner, H., Metzger, D., Peters, R., Smith, I., Grissom, G., Pettinati, H., \& Argeriou, M. (1992). The fifth edition of the Addiction Severity Index. Journal of Substance Abuse Treatment, 9(3), 199-213. https://doi.org/10.1016/07405472(92)90062-s

Mead, G. (1934). Mind, self \& society from the standpoint of a social behaviorist. University of Chicago Press.

Mumola, C., \& Karberg, J. (2006). Drug use and dependence, state and federal prisoners, 2004. In Bureau of Justice Statistics Bulletin (Publication no. NCJ 213530). US Department of Justice. https://www.bjs.gov/content/pub/pdf/dudsfp04.pdf

National Association of Social Workers. (2017). Code of ethics of the National Association of Social Workers. https://www.socialworkers.org/About/Ethics/Code-ofEthics/Code-of-Ethics-English

Pager, D., \& Shepherd, H. (2008). The sociology of discrimination: Racial discrimination in employment, housing, credit, and consumer markets. Annual Review of Sociology, 34, 181-209. https://doi.org/10.1146/annurev.soc.33.040406.131740

Patterson, G. (2013). Prisoner reentry: A public health or public safety issue for social work practice? Social Work in Public Health, 28(2), 129-141. https://doi.org/10.1080/19371918.2011.560822

Peters, R., Greenbaum, P., Edens, J., Carter, C., \& Ortiz, M. (1998). Prevalence of DSMIV substance abuse and dependence disorders among prison inmates. American Journal of Drug and Alcohol Abuse, 24, 573-587. https://doi.org/10.3109/00952999809019608

Petersilia, J. (2009). When prisoners come home: Parole and prisoner reentry. Oxford University Press. https://doi.org/10.1093/acprof:oso/9780195160864.003.0003

Petersilia, J., \& Turner, S. (1991). An evaluation of intensive probation in California. The Journal of Criminal Law and Criminology, 82(3), 610-658. https://doi.org/10.2307/1143747

Pilkinton, M. (2010). TANF recipients' barriers to employability: Substance abuse and domestic violence. Journal of Human Behavior in the Social Environment, 20(8), 1011-1023. https://doi.org/10.1080/10911359.2010.494940 
Poremski, D., Whitley, R., \& Latimer, E. (2014). Barriers to obtaining employment for people with severe mental illness experiencing homelessness. Journal of Mental Health, 23(4), 181-185. https://doi.org/10.3109/09638237.2014.910640

Qenani, E., MacDougall, N., \& Sexton, C. (2014). An empirical study of self-perceived employability: Improving the prospects for student employment success in an uncertain environment. Active Learning in Higher Education, 15(3), 199-213. https://doi.org/10.1177/1469787414544875

Rhode Island Department of Corrections [RIDOC]. (2015). Fiscal year 2015: Population report. http://www.doc.ri.gov/docs/FY15\%20Population\%20Report.pdf

RIDOC. (2017). Fiscal year 2017: Population report. http://www.doc.ri.gov/docs/FY17\%20Annual\%20Population\%20Report.pdf

RIDOC. (2019). Fiscal tear 2019: Population report. http://www.doc.ri.gov/docs/FY19\%20Annual\%20Population\%20Report.pdf

Rothwell, R., \& Arnold, J. (2007). Self-perceived employability: Development and validation of a scale. Personnel Review, 36(1), 23-41. https://doi.org/10.1108/00483480710716704

Schmitz, H. (2011). Why are the unemployed in worse health? The causal effect of unemployment on health. Labour Economics, 18(1), 71-78. https://doi.org/10.1016/j.labeco.2010.08.005

Sentencing Project. (2018). Report of The Sentencing Project to the United Nations Special Rapporteur on Contemporary Forms of Racism, Racial Discrimination, Xenophobia, and Related Intolerance. https://www.sentencingproject.org/publications/un-report-on-racial-disparities/

Skeem J., \& Louden, J. (2006). Toward evidence- based practice for probationers and parolees mandated to mental health treatment. Psychiatric Services, 57, 333-342. https://doi.org/10.1176/appi.ps.57.3.333

Solomon, A., Johnson, K., Travis, J., \& McBride, E. (2004). From prison to work: The employment dimensions of prisoner reentry. Urban Institute Justice Policy Center. https://www.urban.org/sites/default/files/publication/58126/411097-From-Prison-toWork.PDF

Steadman, H., Osher, F., Robbins, P., Case, B., \& Samuels, S. (2009). Prevalence of serious mental illness among jail inmates. Psychiatric Services, 60(6), 761-765. https://doi.org/10.1176/ps.2009.60.6.761

Sterling, A. D. (2014). Friendships and search behavior in labor markets. Management Science, 60(9), 2341-2354. https://doi.org/10.1287/mnsc.2013.1857

Stromwell, L. K. (2001). Mental health needs of TANF recipients. Journal of Sociology and Social Welfare, 28(3), 129-138.

Sun, A-P. (2012). Helping homeless individuals with co-occurring disorders: The four components. Social Work, 57(1), 23-27. https://doi.org/10.1093/sw/swr008 
Tabachnick, B., \& Fidell, L. (2007). Using multivariate statistics (5th ed.). Pearson/Allyn \& Bacon.

Tomaskovic-Devey, D., Thomas, M., \& Johnson, K. (2005). Race and the accumulation of human capital across the career: A theoretical model and fixed-effects application. American Journal of Sociology, 111, 58-89. https://doi.org/10.1086/431779

Visher, C. A., Debus-Sherill, S., \& Yahner, J. (2008). Employment after prison: A longitudinal study of releases in three states. The Urban Institute. https://www.urban.org/sites/default/files/publication/32106/411778-Employmentafter-Prison-A-Longitudinal-Study-of-Releasees-in-Three-States.PDF

Worral, H., Schweizer, R., Marks, E., Yuan, L., Lloyd, C., \& Ramjan, R. (2018). The effectiveness of support groups: A literature review. Mental Health and Social Inclusion, 22 (2), 85-93. https://doi.org/10.1108/mhsi-12-2017-0055

Author note: Address correspondence to Jesse Capece, PhD., LICSW, Department of Social Work, Rhode Island College, 600 Mount Pleasant Ave. Providence, RI 02908. Email: jcapece@ric.edu 